\title{
Effects of food availability and hypoxia on bivalves: the value of using multiple parameters to measure bivalve condition in environmental studies
}

\author{
J. Norkko ${ }^{1,2,4, *}$, C. A. Pilditch ${ }^{3}$, S. F. Thrush ${ }^{1}$, R. M. G. Wells ${ }^{2}$ \\ ${ }^{1}$ National Institute of Water and Atmospheric Research, PO Box 11-115, Hamilton, New Zealand \\ ${ }^{2}$ School of Biological Sciences, The University of Auckland, Private Bag 92019, Auckland, New Zealand \\ ${ }^{3}$ Department of Biological Sciences, University of Waikato, Private Bag 3105, Hamilton, New Zealand
}

${ }^{4}$ Present address: Finnish Institute of Marine Research, PB 33, 00931 Helsinki, Finland

\begin{abstract}
Suspension-feeding bivalves are often included in environmental monitoring because of their trophic position, widespread occurrence and sensitivity to a wide range of environmental factors. Therefore various indices of bivalve condition and growth have been developed, including morphometric condition indices (CI), scope for growth (SFG) and nucleic acid ratios (RNA:DNA ratio, RNA:protein ratio or RNA concentration). The sensitivity of these 3 indices has not previously been compared in the same individual bivalves, yet they are likely to have different temporal scales of detectable response to environmental processes. In 2 laboratory experiments (10 and $24 \mathrm{~d}$ duration) we investigated the combined effect of food availability and sublethal hypoxia on RNA concentration, CI and SFG in juvenile clams Paphies australis. RNA and CI increased rapidly (5 d) following exposure to high food treatment, but only CI showed a negative influence of hypoxia. Although SFG was affected by both food availability and hypoxia, the patterns were opposite to those of RNA and CI. This anomaly could be explained by the instantaneous change in feeding rates and a slower response in respiration rate (which was correlated with CI) to the uniform conditions under which SFG was determined. Our results emphasise the importance of combined effects of environmental factors on bivalve growth, highlighting the overriding influence of food availability, and imply that a combination of measures will give a more accurate representation of growth rate.
\end{abstract}

KEY WORDS: Nucleic acid ratios $\cdot$ RNA $\cdot$ Condition index $\cdot$ Scope for growth $\cdot$ Food availability Hypoxia · Paphies australis

\section{INTRODUCTION}

Suspension-feeding bivalves are often key species in estuarine and coastal habitats (Dame 1993, Gili \& Coma 1998) and changes in their growth rate, abundance and distribution may have cascading effects on both benthic and pelagic ecosystems (Prins et al. 1998, Norkko et al. 2001, Dahlhoff et al. 2002, Ellis et al. 2002, Newell 2004). Because of their trophic position, widespread occurrence and sensitivity to a wide range of growth-facilitating and growth-inhibiting factors, bivalves are often included in ecological monitoring and impact assessment (Goldberg et al. 1978). Bivalve health is commonly assessed by measuring growth rate, which, in its simplest form, is determined by a change in tissue weight or shell length. However, to allow estimation of instantaneous growth rate and to obtain a more detailed picture of the growth process and factors affecting it, various physiological indices of growth and health have been developed, often with the aim of facilitating early detection of environmental change.

Among the most commonly used indices of bivalve health and growth are morphometric condition indices 
(CI) and scope for growth (SFG). Morphometric CI are usually calculated from the ratio of flesh dry weight to some shell characteristic (e.g. weight or length), and because they are simple to determine and provide a useful measure of body composition and energy reserves, they are often used in environmental monitoring (Lucas \& Beninger 1985, Crosby \& Gale 1990). SFG is an integrated physiological and behavioural parameter reflecting the energy balance of an individual, i.e. the energy potentially available for growth, and is derived from rates of energy acquisition (feeding and absorption) and energy expenditure (metabolism and excretion) (Winberg 1960, Smaal \& Widdows 1994). More recently, nucleic acid ratios (RNA:DNA ratio, RNA:protein ratio or RNA concentration; a measure of protein synthesis potential; Houlihan 1991) have been advocated as a sensitive and rapidly responding measure of bivalve short-term growth rate, applicable to ecological studies in natural habitats (Dahlhoff 2004). The general assumption is that biochemical responses precede responses at higher levels of biological organisation and that nucleic acid ratios therefore may provide early indication of environmental perturbation.

Methods for detecting changes in the environment are continually developed and refined, and many modern biological indicators (e.g. biomarkers of chemical exposure) are intended to be very specific, with a clear dose-response relationship, so that the magnitude of the impact can be determined (Schlenk 1999). Unfortunately, these criteria are not always tested (Schlenk 1996). When using growth rate as the response variable, an integrated response to multiple factors with varying magnitudes and directions of effect is measured. Therefore a combination of measures will better explain changes in growth rate, as they have different temporal scales of detectable response and reflect environmental processes that operate at different temporal scales (Mathers et al. 1992, Foster et al. 1993, Norkko et al. unpubl.). Although commonly used indicators of bivalve health, the sensitivity of nucleic acid ratios, SFG and CI has not previously been compared in the same individual bivalves. Here we examine the response of these 3 indices to a growth-facilitating and growth-inhibiting factor under controlled laboratory conditions. The purpose of the study was to clarify the indices' patterns and time scales of response when bivalves are simultaneously affected by factors with opposing effects on growth.

Hypoxia and food availability are 2 factors with clear effects on the health of marine species. The importance of food availability in promoting individual growth and structuring benthic communities is evident (Pearson \& Rosenberg 1987, Herman et al. 1999) and in bivalves it has been positively correlated with nucleic acid ratios
(Wright \& Hetzel 1985, Dahlhoff \& Menge 1996, Menge et al. 1999), SGF (Bayne et al. 1989, Navarro et al. 1992, MacDonald et al. 1998) and CI (Beukema \& Cadée 1991, Rheault \& Rice 1996). Oxygen availability is also a key factor in the metabolic processes of marine invertebrates. Aquatic organisms respond to hypoxia by (1) attempting to maintain oxygen delivery, (2) conserving energy expenditure, and (3) enhancing energetic efficiency and deriving energy from anaerobic sources (Wu 2002). Bivalves in coastal and estuarine areas may frequently be subjected to hypoxia (Diaz \& Rosenberg 1995) and tolerance is highly species-specific. Under laboratory conditions some species survive extended periods of hypoxia and even anoxia (Theede et al. 1969), and some species, including the clam Paphies australis, have evolved efficient strategies for anaerobic energy production (De Zwaan 1977, Carroll \& Wells 1995). Only a few studies have investigated its effects on indices of bivalve health (Sandberg et al. 1996, Sobral \& Widdows 1997), while the influence of hypoxia on bivalve short-term metabolic rates has received considerable attention (e.g. Shumway et al. 1983, Wang \& Widdows 1993a,b).

We compared the short-term response of 3 commonly used indices of bivalve health to hypoxia and food availability. In 2 laboratory experiments we measured adductor muscle RNA concentration (RNA), a morphometric CI and SFG in juvenile clams Paphies australis under the central hypothesis that hypoxia impedes growth in suspension-feeding bivalves, whereas increased food availability has a facilitating influence. In Expt 1 we tested the effect of sub-lethal hypoxia on RNA and CI, and in Expt 2 we tested the interactive effect of food availability and hypoxia on RNA, CI and SFG. The inclusion of 2 environmental factors provides a simplified model of the field where multiple stressors/facilitators are working simultaneously. In standardising the experimental conditions and measuring the indices on the same individuals, the sensitivity of the indices could be directly compared. Moreover, through regular sampling during the experiment the response time of the indices could be determined.

\section{MATERIALS AND METHODS}

Study species. Paphies australis (Mesodesmatidae) is an intertidal suspension-feeding bivalve, which normally inhabits relatively coarse sediments and is common near the mouths of estuaries (Morton \& Miller 1968). Juveniles ( 25 to $35 \mathrm{~mm}$ ) were chosen for the present study, as they exhibit rapid somatic growth and are predicted to be more sensitive to hypoxia than adults. $P$. australis can experience hypoxia during the 
regular immersion and emersion cycles, due both to shell closure and depletion of oxygen in shallow tidal pools. In addition, they may be exposed to hypoxia under macroalgal (Ulva) mats (Busing 1999). P. australis can survive up to $7 \mathrm{~d}$ under completely anoxic conditions in the laboratory and have enzymatic adaptations for energy production under periodic environmental hypoxia (Carroll \& Wells 1995). Thus only sublethal effects of moderate hypoxia were expected in this study.

General experimental setup. Juvenile Paphies australis $(29.8 \pm 2.9 \mathrm{~mm}$ in Expt 1 and $30.4 \pm 2.6 \mathrm{~mm}$ in Expt 2) for both experiments were collected high on the shore in a sandy tributary estuary of Tauranga Harbour, New Zealand $\left(37^{\circ} 67^{\prime} \mathrm{S}, 176^{\circ} 16^{\prime} \mathrm{E}\right)$, and transported to the laboratory approximately $1 \mathrm{~h}$ away in aerated seawater. Bivalves (42 and 50 per aquarium in Expts 1 and 2, respectively) were placed in 551 aquaria filled with $5 \mu \mathrm{m}$ filtered seawater (salinity 34 to $35 \%$ ) without sediment and acclimated to laboratory conditions at the collection site temperature $\left(21^{\circ} \mathrm{C}\right.$ in Expt 1 and $17^{\circ} \mathrm{C}$ in Expt 2). Initial bivalve size did not differ among treatments and aquaria were positioned to ensure uniform temperature and light conditions in all treatments. During the acclimation period (4 $\mathrm{d}$ in Expt 1 and 10 d in Expt 2) $\mathrm{O}_{2}$ saturation was maintained at $100 \%$ by bubbling with air-stones and the bivalves were fed Isochrysis galbana (see below for rations). Small submersible pumps were placed in all aquaria to ensure a uniform concentration of both $\mathrm{O}_{2}$ and food. Every second day biodeposits and food particles were siphoned from the aquaria and $30 \mathrm{l}$ of the water was changed to prevent ammonia build-up.

At the end of the acclimation period, aquaria were randomly allocated to experimental treatments (see below). Different levels of hypoxia were achieved by bubbling with a variable mixture of nitrogen gas and air. In hypoxia treatments, a sheet of plastic was placed on the water surface to prevent diffusion of $\mathrm{O}_{2}$ from the air. $\mathrm{O}_{2}$ levels in the aquaria were measured 3 times a day with a calibrated YSI Model 58 Dissolved Oxygen Meter (Yellow Springs Instruments).

Expt 1: Effect of hypoxia. In this experiment the short-term effects of hypoxia on RNA and CI were tested during a $10 \mathrm{~d}$ experiment. The hypoxia treatments were $100,80,60,40$ and $20 \% \mathrm{O}_{2}$ saturation, with 1 aquarium per treatment and 42 bivalves per aquarium. The acclimation ration of $10 \mathrm{ml}$ concentrated Isochrysis galbana culture (aquarium concentration = $2.5 \times 10^{5}$ cells $\mathrm{ml}^{-1}$ or $8 \mathrm{mg} \mathrm{l}^{-1}$ ) fed twice daily was maintained for the duration of the experiment. The daily ration corresponded to $14 \%$ of bivalve tissue dry weight at the start of the experiment and was not expected to limit growth (Epifanio \& Ewart 1977). On Day 0, 2 bivalves were removed from each aquarium for analysis of RNA and CI, before $\mathrm{O}_{2}$ saturation was lowered to the designated levels. Thereafter, 10 bivalves were removed for analysis from each aquarium 2, 5, 8 and $10 \mathrm{~d}$ after initiation of hypoxia.

Expt 2: Effect of food availability and hypoxia. In this experiment the interactive effects of food availability and hypoxia on RNA, CI and SFG were tested. The experiment lasted $24 \mathrm{~d}$, to extend the time scale from Expt 1. Treatments were low, medium and high food at $100 \% \mathrm{O}_{2}$ saturation (Low 100\%, Medium 100\% and High $100 \%$, respectively) and low and high food at $40 \% \mathrm{O}_{2}$ saturation (Low $40 \%$ and High $40 \%$, respectively), with 1 aquarium per treatment and 50 bivalves per aquarium. To induce only sublethal effects, $40 \%$ $\mathrm{O}_{2}$ saturation was chosen, as some mortality had been recorded at $20 \%$ in Expt 1 . During the $10 \mathrm{~d}$ acclimation period, all bivalves were fed at the Medium level: $4 \mathrm{ml}$ of concentrated Isochrysis galbana culture twice daily (aquarium concentration $=1.0 \times 10^{5}$ cells ml ${ }^{-1}$ or $3 \mathrm{mg}$ $\mathrm{l}^{-1}$ ), which represented a daily ration of $5 \%$ of bivalve tissue dry weight. After initiation of hypoxia and food treatments, the Low treatments received no food, the Medium treatment continued to receive the acclimation period ration, and the High treatments were fed $12 \mathrm{ml}$ concentrated algae twice daily (aquarium concentration $=3.0 \times 10^{5}$ cells $\mathrm{ml}^{-1}$ or $9 \mathrm{mg} \mathrm{l}^{-1}$ ), a daily ration equivalent to $14 \%$ of bivalve tissue dry weight. On Day 0, 2 bivalves were removed from each aquarium for determination of RNA, CI and SFG, before $\mathrm{O}_{2}$ saturation was lowered to the designated levels and the different food treatments implemented. Twelve bivalves were removed from each aquarium for RNA and CI analyses on Days 5, 12, 18 and 24. In addition, SFG was determined for the bivalves sampled on Days 12 and 24.

Scope for growth measurements. SFG was measured in Expt 2 to allow comparison of RNA, CI and SFG in the same individuals. SFG was determined under uniform conditions for all treatments, where differences in response can be attributed to the treatments to which bivalves have previously been subjected, to allow comparison of the short-term adaptability of bivalve feeding behaviour and physiology. As SFG cannot be measured under no-food conditions, the Medium food level was used. All measurements were conducted at the experimental temperature $\left(17^{\circ} \mathrm{C}\right.$ ) and $100 \% \mathrm{O}_{2}$ saturation. It was not possible to measure SFG at the level of the individual bivalve due to their small size. Instead the 12 bivalves sampled from each treatment were divided into 3 replicate groups consisting of 4 individuals on which the physiological rates were measured.

Feeding measurements were performed in flowthrough chambers $(1.7$ l volume, $18.5 \times 13 \times 7 \mathrm{~cm}: 1 \times \mathrm{w}$ $\times \mathrm{h}$ ) and peristaltic pumps circulated seawater from a 
header tank through the chambers at a rate of $70 \mathrm{ml}$ $\mathrm{min}^{-1}$. From each treatment, the 12 bivalves were divided among 3 feeding chambers and acclimated in filtered seawater for $12 \mathrm{~h}$ prior to the start of the feeding measurements to standardise hunger levels. Before starting the feeding measurements, biodeposits produced during the acclimation period were removed. Subsequently, Isochrysis galbana was added to the header tank at a concentration equivalent to the Medium food treatment. Algal concentration in the header tank was monitored hourly with a fluorometer and algae were added as required to maintain a near constant concentration. After $5 \mathrm{~h}$, biodeposits were collected from the feeding chambers and the bivalves were moved to respiration chambers (4 per chamber).

Feeding and absorption rates were calculated in accordance with the biodeposit method described by Hawkins et al. (1996) (Table 1). Paphies australis generally produce very few pseudofaeces (pers. obs.) and none were produced in these experiments. The amount and organic content of faeces and diet was determined by filtering samples onto washed, preashed and weighed GF/F filters and rinsing with isotonic ammonium formate to remove salt. Filters were then dried at $60^{\circ} \mathrm{C}$ until constant weight and the organic fraction was calculated from the weight loss after combustion at $450^{\circ} \mathrm{C}$ for $6 \mathrm{~h}$.

Respiration rates $(\mathrm{R})$ were measured in filtered seawater in sealed respiration chambers. Thirty minutes after the bivalves were placed in the chambers, a water sample was collected by pressing down the o-ring sealed lid into the chamber, forcing water out through a sampling port. $\mathrm{O}_{2}$ concentration was measured immediately and a further 2 samples were collected in this manner before the incubation was terminated. Initial $\mathrm{O}_{2}$ saturations were between 96 and 100\% and incubations were stopped before they dropped below $78 \%\left(6.1 \mathrm{mg} \mathrm{l}^{-1}\right)$. An additional chamber without bivalves was included to account for bacterial respiration. $\mathrm{O}_{2}$ consumption was calculated from the change in $\mathrm{O}_{2}$ concentration between samples, after accounting for changes in volume, and corrected for changes in the control chamber.

Tissue dry weight of bivalves used in the experiment ranged from 0.07 to $0.23 \mathrm{~g}$. To account for differences in size, feeding and respiration rates were scaled to a standard bivalve of $0.15 \mathrm{~g}$ tissue dry weight (dwt) using the following equation:

$$
R_{\mathrm{s}}=\left(\mathrm{dwt}_{\mathrm{s}} / \mathrm{dwt}_{\mathrm{obs}}\right)^{b} R_{\mathrm{obs}}
$$

where $R_{\mathrm{s}}$ is the standardised rate, dwt $\mathrm{s}_{\mathrm{s}}$ is the dry tissue weight $(0.15 \mathrm{~g})$ of the standard bivalve, $\mathrm{dwt}_{\mathrm{obs}}$ is the average dry tissue weight $(g)$ of the observed bivalve, $R_{\text {obs }}$ is the observed rate per animal (i.e. measured rate divided by 4 , the number of individuals per chamber), and $b$ is the average coefficient of 0.66 for scaling feeding and respiration rates with weight (Bricelj \& Shumway 1991).

SFG $\left(\mathrm{J} \mathrm{h}^{-1}\right)$ was calculated as the difference between energy gained (net organic absorption rate, NOAR; Table 1) minus the energy expended (R). NOAR and R were converted to energy equivalents assuming $1 \mathrm{mg}$ organic matter $=20.78 \mathrm{~J}\left(\right.$ Crisp 1971) and $1 \mu \mathrm{mol} \mathrm{O} \mathrm{O}_{2}=$ $0.456 \mathrm{~J}$ (Gnaiger 1983), respectively. Losses due to ammonia excretion were not included in the SFG calculation, as they generally are a negligible fraction of the energy budget (Widdows 1993).

RNA analysis. At the end of the SFG measurements and after removal of additional bivalves from the aquaria on Days 5 and 18, the adductor muscles were immediately excised under a dissecting microscope, frozen in liquid nitrogen, stored at $-70^{\circ} \mathrm{C}$ and freeze dried prior to determination of total RNA concentration $\left(\mu \mathrm{g} \mathrm{mg}^{-1}\right)$. Muscle tissue from 2 individuals was pooled to provide sufficient material; it was pulverised in a glass mortar and 10 to $15 \mathrm{mg}$ was used for the analysis. Extraction and spectrophotometric quantification of RNA was based on Chomczynski (1993), using TRI Reagent $^{\mathrm{TM}}$ (Molecular Research Centre, \# TR118/200). The tissue was homogenised in the reagent using a plastic micropestle, left at room temperature for $15 \mathrm{~min}$ and centrifuged at $12000 \times g$ for $10 \mathrm{~min}$ at $4^{\circ} \mathrm{C}$ to

Table 1. Calculation of feeding and digestion processes used in scope for growth estimations after Hawkins et al. (1996). TPM = total particulate matter, $\mathrm{PIM}=$ particulate inorganic matter, $\mathrm{POM}=$ particulate organic matter, $f$ POM $=$ organic fraction

\begin{tabular}{|c|c|c|c|}
\hline Parameter & Acronym & Unit & Calculation \\
\hline Clearance rate & $\mathrm{CR}$ & $\mathrm{ml} \mathrm{h}^{-1}$ & $\left(\mathrm{PIM}_{\text {faeces }}+\mathrm{PIM}_{\text {pseudofaeces }}\right) / \mathrm{PIM}_{\text {diet }}$ \\
\hline Filtration rate & FR & $\mathrm{mg} \mathrm{h}^{-1}$ & $\mathrm{CR} \times \mathrm{TPM}_{\text {diet }}$ \\
\hline Rejection rate & $\mathrm{RR}$ & $\mathrm{mg} \mathrm{h}^{-1}$ & mg pseudofaeces $\mathrm{h}^{-1}$ \\
\hline Ingestion rate & IR & $\mathrm{mg} \mathrm{h}^{-1}$ & $\mathrm{FR}-\mathrm{RR}$ \\
\hline Net organic ingestion rate & NOIR & $\mathrm{mg} \mathrm{h}^{-1}$ & $\left(\mathrm{FR} \times f \mathrm{POM}_{\text {diet }}\right)-\left(\mathrm{RR} \times f \mathrm{POM}_{\text {pseudofaeces }}\right)$ \\
\hline Net organic absorption rate & NOAR & $\mathrm{mg} \mathrm{h}^{-1}$ & NOIR $-\left(\right.$ mg faeces $\mathrm{h}^{-1} \times f$ POM $\left._{\text {faeces }}\right)$ \\
\hline Net absorption efficiency from ingested organics & NAEIO & Fraction & NOAR/NOIR \\
\hline
\end{tabular}


remove insoluble material. The supernatant was separated into an aqueous phase (colourless), an interphase (white) and an organic phase (red) through the addition of chloroform, vigorous shaking and subsequent centrifugation at $12000 \times g$ for $15 \mathrm{~min}$ at $4^{\circ} \mathrm{C}$. RNA was precipitated from the aqueous phase through the addition of isopropanol and subsequent centrifugation at $12000 \times g$ for $10 \mathrm{~min}$ at $22^{\circ} \mathrm{C}$. The pellet was washed twice with $75 \%$ ethanol and then solubilised in $0.5 \%$ SDS, incubated for $10 \mathrm{~min}$ at $60^{\circ} \mathrm{C}$, and cooled to room temperature. RNA was quantified by reading the absorbance against $0.5 \% \mathrm{SDS}$ at 260 and $280 \mathrm{~nm}$. As all samples had a $260 / 280$ ratio $>1.60$, i.e. no protein contamination, all samples were included in the dataset. At $260 \mathrm{~nm}$ one absorbance unit corresponds to $40 \mu \mathrm{g} \mathrm{ml}^{-1}$ pure RNA and the results were expressed as $\mu \mathrm{g}$ RNA $\mathrm{mg}^{-1}$ tissue dry weight.

Morphometric condition index. CI was determined using the gravimetric index recommended by Crosby \& Gale (1990):

$$
\begin{aligned}
\text { CI-grav }= & \text { flesh dry weight } \times 1000 /(\text { whole live } \\
& \text { weight }- \text { shell dry weight })
\end{aligned}
$$

This index estimates the proportion of the available shell cavity capacity utilised by the bivalve's soft tissues and thus reflects recent tissue accrual or loss. An index based on flesh dry weight/shell dry weight (CIshell) was also calculated for all bivalves and the same conclusions were reached with both indices (CI-shell data not presented). While the CI-shell index compares metabolism directed towards either shell growth or soft tissues, and does not account for possible variations in shell shape or thickness, the CI-grav index is decoupled from shell growth and shape. The weight of muscle tissue used for RNA analysis was included in the calculation of flesh dry weight.

Data analysis. To determine whether RNA and CI varied among treatments on different sampling dates in Expt 1, linear regression was used with oxygen saturation as independent variable. To determine whether RNA, CI, respiration rate and SFG varied among treatments and through time in Expt 2, a 2-way fixed factor ANOVA was used. When significant interactions were indicated, differences between treatments on a given sampling day were further explored using Tukey's multiple comparison tests. In addition, Dunnett's test (testing against one control group, $\alpha=$ 0.05) was used to test RNA, CI, respiration rate and SFG within a treatment over time against Day 0, to detect the point at which the index differed significantly from the initial value. Correlations between indices were examined using either the Pearson Product Moment Correlation or Spearman Rank Correlation as appropriate. Prior to analysis, data were examined for homogeneity of variances ( $F$ test) and normality (Kolmogorov-Smirnov), and ranktransformed where necessary. As the individual bivalve's physiological response was considered the replicate, treatments were not replicated at the level of the aquaria and any significant differences were assumed to be due to the applied treatment. Care was taken to ensure uniform general conditions for all aquaria (e.g. temperature, light, same water source, same food source). Furthermore, sampling over time reduced the risk of misinterpreting erratic treatment effects. For the RNA and CI measurements, a pool measurement from 2 individuals was used (yielding 5 or 6 replicates per treatment per sampling occasion in Expts 1 and 2, respectively), whereas for the respiration rate and SFG measurements a replicate consisted of 4 individuals. Statistical analyses were performed using StatView 5.0 for Macintosh computers and p < 0.05 was used as the general significance level.

\section{RESULTS}

\section{Expt 1: Effect of hypoxia}

Although hypoxia levels varied somewhat from the nominal levels, differences between treatments were maintained for the $10 \mathrm{~d}$ period (Fig. 1A). After $2 \mathrm{~d}$ of hypoxia, individuals in the $20 \%$ treatment did not appear to be filtering at the same rate as in the other treatments, with smaller amounts of faeces produced and some individuals gaping excessively. The first mortalities were observed after $3 \mathrm{~d}$ of hypoxia, with 1 dead individual in the $20 \%$ and 1 in the $60 \%$ treatment. Dead bivalves were immediately removed from the aquaria. By the end of the experiment, the $20 \%$ treatment recorded the highest mortality with 16 dead individuals; in the other treatments mortality rates were low: $100 \% \mathrm{O}_{2}=2,80 \% \mathrm{O}_{2}=8,60 \% \mathrm{O}_{2}=1$ and $40 \% \mathrm{O}_{2}=0$ dead individuals.

RNA was not affected by the level of hypoxia on any of the sampling dates (Fig. 1B, Table 2). There was a weak decline in RNA in all treatments over the course of the experiment, but this trend was only significant in the $100 \%$ treatment $\left(\mathrm{r}^{2}=0.229, \mathrm{p}=0.0156\right)$. CI was more variable, but differences among treatments were not consistent through time or obviously related to treatment level (Fig. 1C). For example, the lowest CI was observed at 100 and $20 \% \mathrm{O}_{2}$ saturation and the highest at intermediate saturations. Over time, the negative relationship between $\mathrm{O}_{2}$ saturation and $\mathrm{CI}$ became somewhat stronger (Table 2). However, this pattern was driven by a slow decline in CI over time in the $100 \%$ treatment $\left(r^{2}=0.345, p=0.0020\right)$ and was thus not related to hypoxia. No significant correlation was found between RNA and CI ( $p>0.05)$. 


\section{Expt 2: Effect of food availability and hypoxia}

$\mathrm{O}_{2}$ saturations in the different treatments remained relatively stable throughout the experiment, ranging between 89 and $99 \%$ in the $100 \% \mathrm{O}_{2}$ treatments, and between 32 and $51 \%$ in the $40 \% \mathrm{O}_{2}$ treatments (Fig. 2A); unlike Expt 1, no mortality was observed in
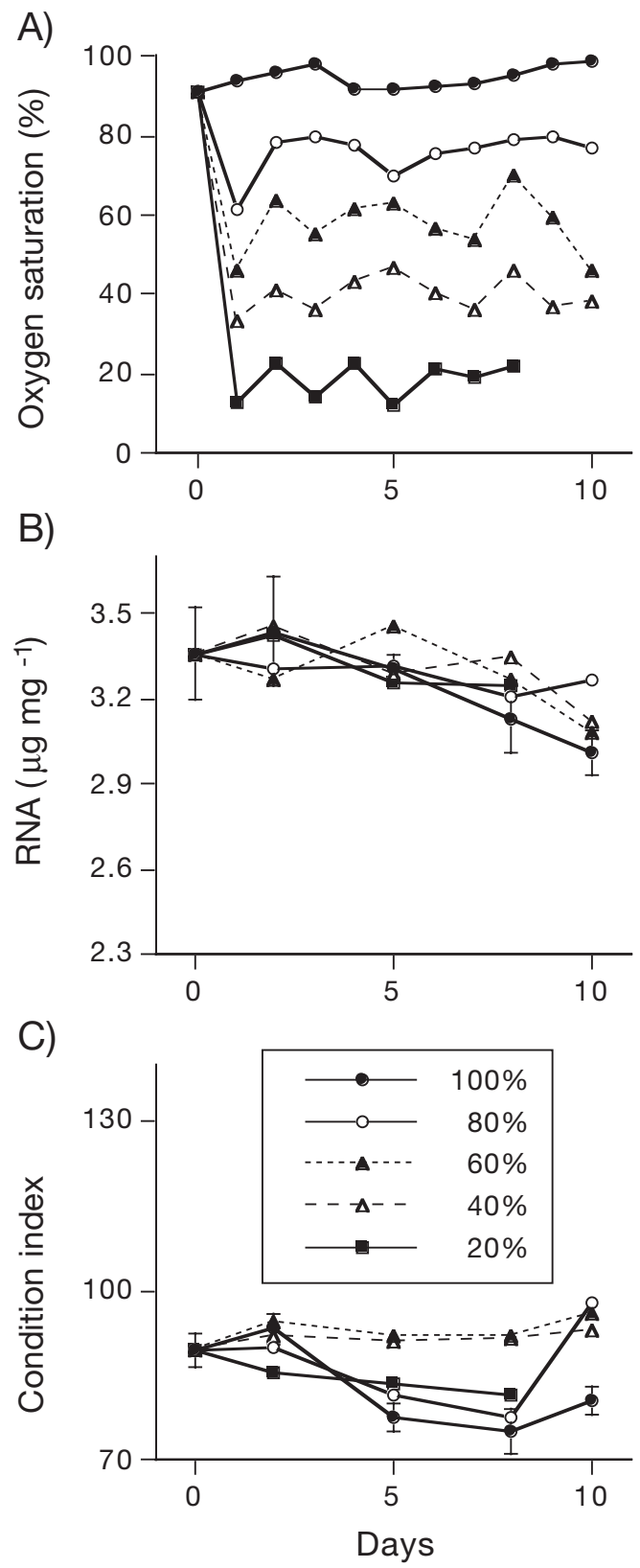

Fig. 1. Paphies australis. Expt 1: (A) Oxygen saturation in the aquaria during the experiment, and the corresponding change in (B) RNA concentration in adductor muscle and (C) condition index. Data in (B) and (C) are the mean of 5 replicate samples and all treatments exhibited similar variability, but for clarity only SE for the $100 \%$ treatment is shown. Scales are comparable with Fig. 2 any treatment. However, over time significant differences in both RNA, CI, respiration rates and SFG were found between treatments (Table 3, Figs. 2 \& 3).

Food availability, not hypoxia, appeared to be the major factor affecting RNA. In both the High $100 \%$ and High $40 \%$ treatments RNA increased rapidly during the experiment (Fig. 2B) and no significant differences between these 2 treatments were detected on any sampling date (Table 4). In contrast, RNA decreased slowly in the Low $100 \%$ and Low $40 \%$ treatments, with no significant differences detected between these treat-

Table 2. Paphies australis. Expt 1: Oxygen saturation (20 to $100 \%$ ) as predictor of RNA concentration and condition index (CI) after 2 to $10 \mathrm{~d}$ exposure to different oxygen levels. (+), (-): relationship was positive or negative

\begin{tabular}{|lcccc|}
\hline Day & \multicolumn{2}{c}{ RNA } & $\mathrm{r}^{2}$ CI \\
& $\mathrm{r}^{2}$ & $\mathrm{p}$ & $\mathrm{p}$ \\
\hline 2 & $0.005(-)$ & 0.7413 & $0.104(+)$ & 0.1150 \\
5 & $0.009(+)$ & 0.6582 & $0.155(-)$ & 0.0513 \\
8 & $0.042(-)$ & 0.3365 & $0.189(-)$ & 0.0339 \\
10 & $0.027(-)$ & 0.5300 & $0.304(-)$ & 0.0217 \\
\hline
\end{tabular}

Table 3. Paphies australis. Expt 2: Results of a 2-way fixed factor ANOVA testing the effects of different food level-oxygen saturation treatments and days of exposure (time) on RNA adductor concentration and CI (rank-transformed data), and respiration rate and scope for growth (SFG) (non-transformed data). RNA and CI were measured 5 times during the experiment (Days 0, 5, 12, 18, 24) whereas respiration rate and SFG were measured 3 times (Days 0, 12, 24). All results are significant

\begin{tabular}{|lrrrr|}
\hline Variable & SS & df & \multicolumn{1}{c|}{$F$} & $\mathrm{p}$ \\
Factor & & & & \\
\hline RNA & & & & \\
Time & 16702.60 & 4 & 7.76 & $<0.0001$ \\
Treatment & 62542.93 & 4 & 29.04 & $<0.0001$ \\
Time $\times$ Treatment & 37412.73 & 16 & 4.34 & $<0.0001$ \\
Residual & 66758.53 & 124 & & \\
CI & & & & \\
Time & 11954.84 & 4 & 5.73 & 0.0003 \\
Treatment & 67410.17 & 4 & 32.28 & $<0.0001$ \\
Time $\times$ Treatment & 36345.56 & 16 & 4.35 & $<0.0001$ \\
Residual & 65255.00 & 125 & & \\
Respiration & & & & \\
Time & 7.18 & 2 & 13.37 & $<0.0001$ \\
Treatment & 11.89 & 4 & 11.06 & $<0.0001$ \\
Time $\times$ Treatment & 7.18 & 8 & 3.34 & 0.0075 \\
Residual & 8.06 & 30 & & \\
SFG & & & & \\
Time & 29.62 & 2 & 8.53 & 0.0012 \\
Treatment & 84.09 & 4 & 12.11 & $<0.0001$ \\
Time $\times$ Treatment & 65.84 & 8 & 4.74 & 0.0008 \\
Residual & 52.08 & 30 & & \\
& & & & \\
\hline
\end{tabular}



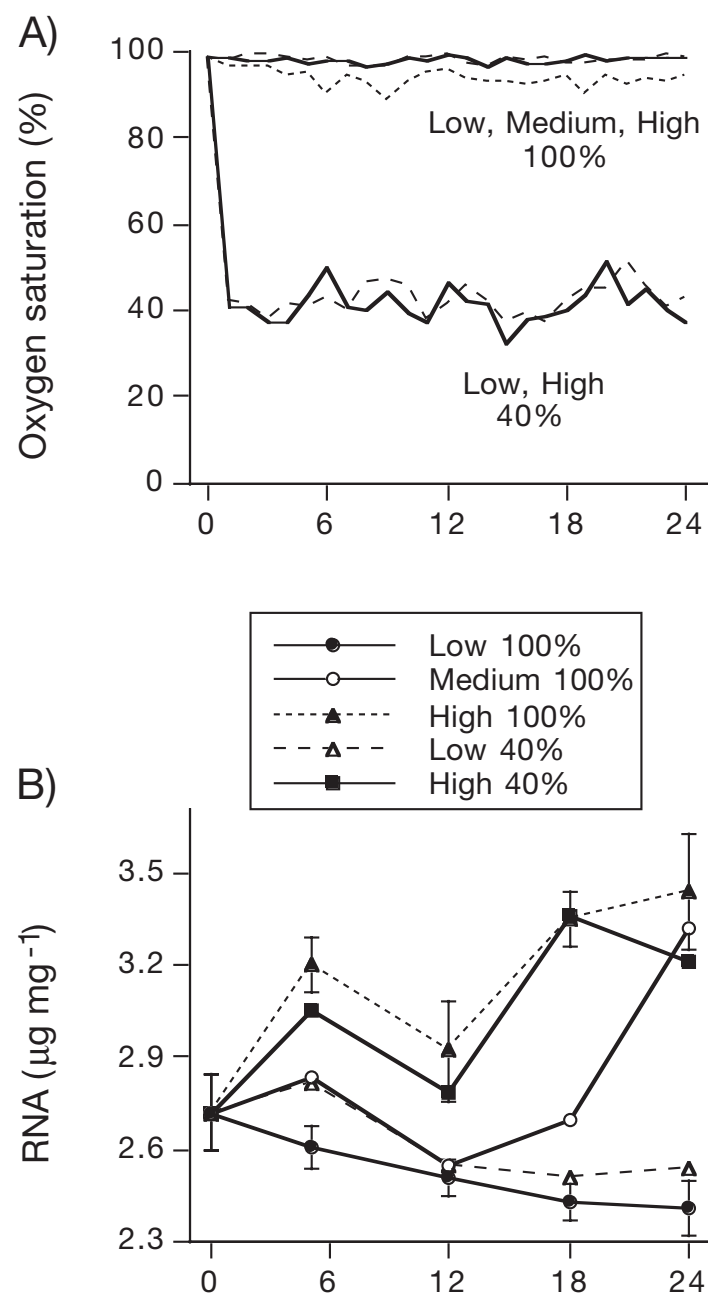

C)

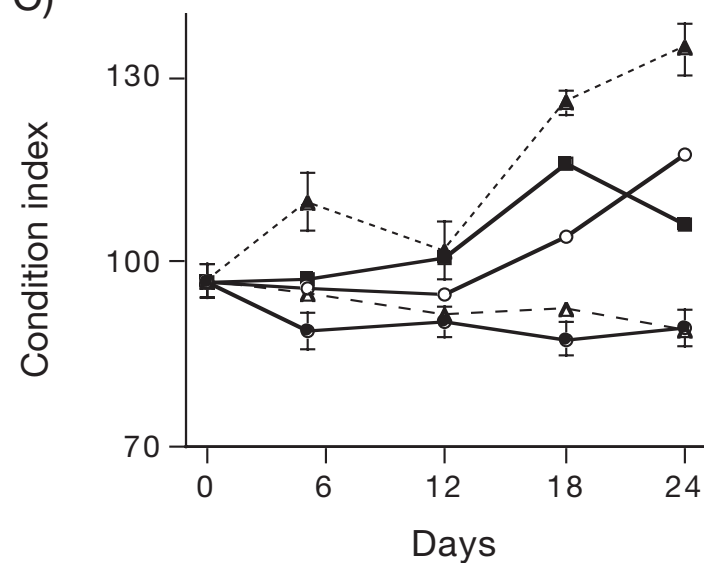

Fig. 2. Paphies australis. Expt 2: (A) Oxygen saturation in the aquaria during the experiment, and the corresponding change in (B) RNA concentration in adductor muscle and (C) condition index as a function of the 3 food levels (Low, Medium, High) and level of oxygen saturation (40\%, 100\%). Data in (B) and (C) are the mean of 6 replicate samples and all treatments exhibited similar variability, but for clarity only SE for the Low $100 \%$ and High $100 \%$ treatments are shown ments on any sampling date. RNA was significantly greater in both high compared with both low food treatments on Days 5, 18 and 24. In the Medium 100\% treatment RNA increased rapidly towards the end of the experiment (Fig. 2B), so that by Day 24 it was not significantly different from the 2 high food treatments (High 100\% and High $40 \%$ ) (Table 4).

CI followed a similar pattern to RNA, with clearly increasing indices in the high and medium food treatments (Fig. 2C), and there was a significant overall positive correlation between the 2 indices $(\mathrm{r}=0.805$, $\mathrm{p}<0.0001)$. Comparing RNA and CI in the different treatments with Day 0 (Dunnett's test) further demonstrated the comparable temporal trends in the indices. In the High $100 \%$ and High $40 \%$ treatments both RNA and CI had increased significantly by Day 18, whereas this increase was significant by Day 24 in the Medium $100 \%$ treatment. The slow decrease in both indices in the Low $100 \%$ and Low $40 \%$ treatments was not significant even after $24 \mathrm{~d}$ (Dunnett's test, $\mathrm{p}>0.05$ ). Nevertheless, CI appeared somewhat more affected by hypoxia compared with RNA. For example, after $5 \mathrm{~d}$ no significant difference in CI was found between the

Table 4. Paphies australis. Expt 2: Results of post-hoc Tukey multiple comparison tests between treatments on a given sampling day for RNA and CI (rank-transformed data) and respiration rate and SFG (non-transformed data). See Table 3 for results of overall ANOVA. L, M and $\mathrm{H}$ denote the food level (Low, Medium, High); 40 and 100 denote the level of oxygen saturation $(40 \%, 100 \%)$. Lines connect treatments not significantly different from each other $(p>0.05)$

\begin{tabular}{|c|c|c|c|c|c|c|}
\hline \multirow{2}{*}{$\begin{array}{l}\text { Variable } \\
\text { RNA }\end{array}$} & \multirow{2}{*}{$\frac{\text { Day }}{5}$} & \multicolumn{5}{|c|}{ Treatments } \\
\hline & & L100 & L40 & M100 & $\mathrm{H} 40$ & H100 \\
\hline & 12 & L100 & L40 & M100 & $\mathrm{H} 40$ & H100 \\
\hline & 18 & L100 & L40 & M100 & $\mathrm{H} 40$ & H100 \\
\hline & 24 & L100 & L40 & $\mathrm{H} 40$ & M100 & H100 \\
\hline \multirow[t]{4}{*}{ CI } & 5 & L100 & L40 & M100 & $\mathrm{H} 40$ & H100 \\
\hline & 12 & L100 & L40 & M100 & $\mathrm{H} 40$ & H100 \\
\hline & 18 & L100 & L40 & M100 & $\mathrm{H} 40$ & H100 \\
\hline & 24 & L100 & L40 & $\mathrm{H} 40$ & M100 & H100 \\
\hline \multirow[t]{2}{*}{ Respiration } & 12 & L40 & L100 & $\mathrm{H} 40$ & M100 & H100 \\
\hline & 24 & L40 & L100 & $\mathrm{H} 40$ & M100 & H100 \\
\hline \multirow[t]{2}{*}{ SFG } & 12 & L40 & $\mathrm{H} 40$ & M100 & H100 & L100 \\
\hline & 24 & L40 & H100 & $\mathrm{H} 40$ & M100 & L100 \\
\hline
\end{tabular}



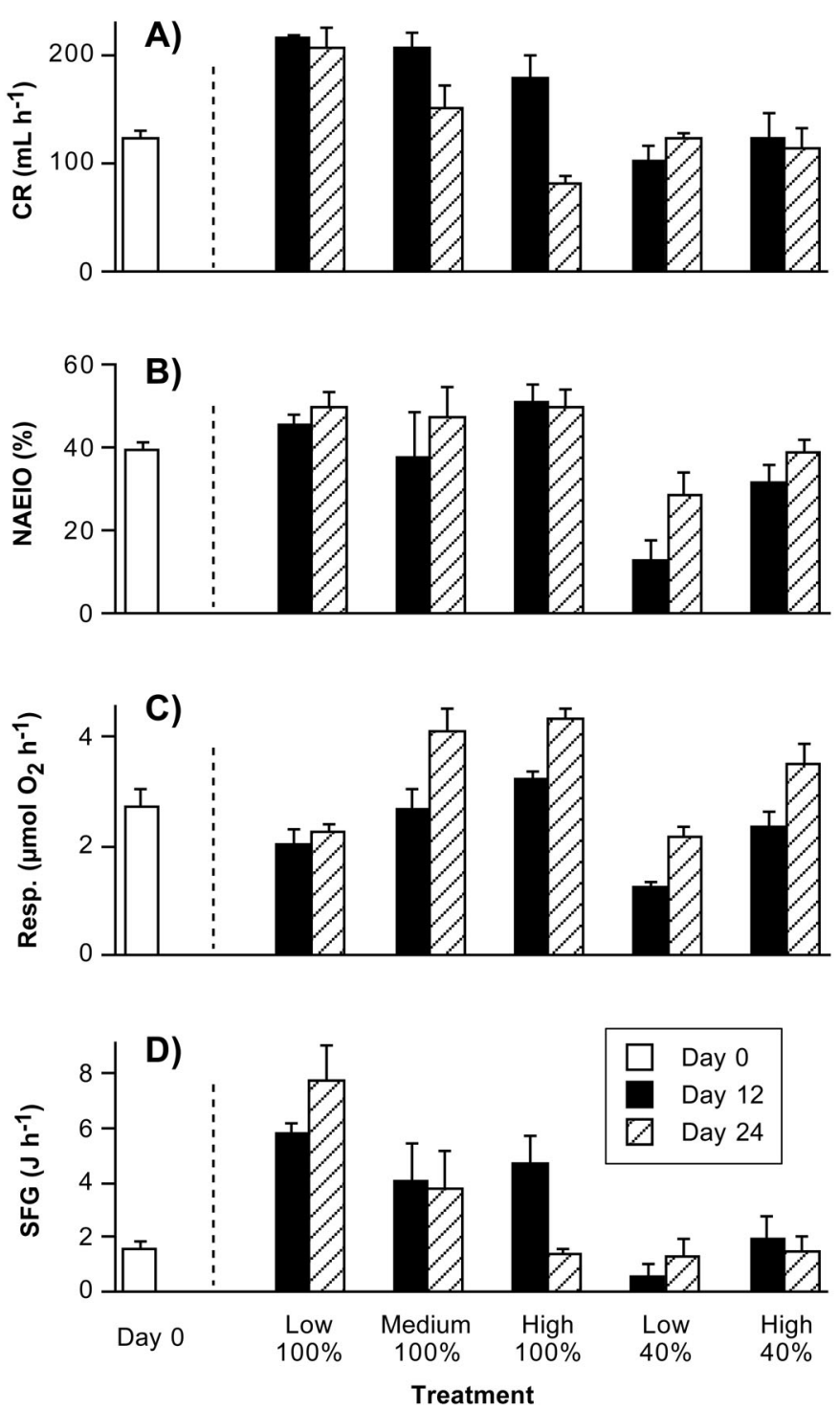

Fig. 3. Paphies australis. Expt 2: Weight standardised (A) clearance rate $(\mathrm{CR}),(\mathrm{B})$ absorption rate, $(\mathrm{C})$ respiration rate and (D) scope for growth (SFG) at the start of the experiment (Day 0) and after 12 and $24 \mathrm{~d}$ exposure to the food (Low, Medium, High)-oxygen saturation $(40 \%, 100 \%)$ treatments $($ mean $+\mathrm{SE}, \mathrm{n}=3)$. Rates were determined under standard conditions of medium food and $100 \%$ oxygen saturation.

NAEIO: net absorption efficiency from ingested organics

High $40 \%$ and Low $40 \%$ treatments, whereas already at this stage significantly higher RNA was found in the High $40 \%$ treatment compared with the Low $40 \%$ treatment (Table 4, Fig 2B,C). Over time the difference between CI in the High $100 \%$ and High $40 \%$ treatments increased, and by Day 24 CI in the High $40 \%$ treatment had started decreasing. However, no significant difference in CI was found between the Low $100 \%$ and Low $40 \%$ treatments on any sampling day (Table 4).
SFG is a combination of both feeding, digestion and respiration responses. Hypoxia clearly affected bivalve feeding behaviour with consistently low clearance rates in the Low $40 \%$ and High $40 \%$ treatments, even though rates were determined at $100 \% \mathrm{O}_{2}$ saturation (Fig. 3A). In contrast, in the $100 \%$ treatments, clearance rates changed over time, but were always highest in the Low $100 \%$ treatment and successively lower in the Medium 100\% and High 100\% treatments. Hypoxia also resulted in an absorption efficiency that was 40 to $70 \%$ lower in the Low $40 \%$ compared with the Low $100 \%$ treatment, and 20 to $40 \%$ lower in the High $40 \%$ compared with the High $100 \%$ treatment (Fig. 3B).

Respiration rates were estimated as part of the SFG measurements (Fig. 3C) and proved to be positively correlated with RNA ( $\mathrm{r}=0.734, \mathrm{p}<0.0001)$ and CI $(\mathrm{r}=$ 0.775, p < 0.0001). Similarly to RNA and CI, respiration rates appeared to respond to food availability, while being less affected by hypoxia. Even on Day 24 respiration rates in the Low $100 \%$ and Low $40 \%$ treatments were not significantly different from each other (Table 4). The same applied to the High 100\% and High $40 \%$ treatments. However, the power of the analysis to detect significant differences was relatively low $(n=3)$. Respiration rates in the different treatments were also compared over time (Dunnett's test), but only differed significantly from Day 0 in the High 100\% (Day 24) and Low $40 \%$ treatments (Day 12). As respiration rate is positively related to $\mathrm{O}_{2}$ saturation, the low respiration rates exhibited by bivalves from the Low $40 \%$ and High treatments as measured under fully oxygenated conditions would likely have been even lower if measured at $40 \% \mathrm{O}_{2}$ saturation.

Average SFG was positive in all treatments on all 3 occasions (Fig. 3D), but varied significantly between treatments and over time (Table 3). However, SFG did not exhibit the same pattern as RNA and CI, and under the uniform conditions used for the SFG measurements, a weak negative correlation was suggested between these measures (SFG vs. RNA, $r=-0.326$, $p=0.0639$; SFG vs. CI, $r=-0.265, p=0.1354)$. The instantaneous increase in feeding rate when the bivalves in the Low $100 \%$ treatment were supplied with food, coupled with low respiration rate, resulted in the highest SFG, followed by the Medium $100 \%$ and High $100 \%$ treatments. Lowest SFG was found in the Low $40 \%$ treatment. By Day 24, SFG in the High $100 \%$, High $40 \%$ and Low $40 \%$ treatments was significantly lower than in the Low $100 \%$ treatment (Table 4). SFG in the different treatments were also compared over time (Dunnett's test), but only differed significantly from Day 0 in the High $100 \%$ (Day 12) and Low $100 \%$ treatments (Days 12 and 24).

To test the interaction between food availability and hypoxia, RNA, CI, respiration rate and SFG were com- 
Table 5. Paphies australis. Expt 2: Results of a 2-way fixed factor ANOVA testing the interaction between food level (Low, High) and oxygen saturation $(40 \%, 100 \%)$ on RNA adductor concentration and CI (rank-transformed data), respiration rate and SFG (non-transformed data) on Day 24. Significant results are indicated in bold

\begin{tabular}{|lrrrr|}
\hline Variable & \multicolumn{1}{c}{ SS } & df & \multicolumn{1}{c|}{$F$} & $\mathrm{p}$ \\
Factor & & & & \\
\hline RNA & & & & \\
Food & 864.00 & 1 & 70.15 & $<\mathbf{0 . 0 0 0 1}$ \\
Oxygen & 0.17 & 1 & 0.01 & 0.9086 \\
Food $\times$ Oxygen & 37.50 & 1 & 3.05 & 0.0964 \\
Residual & 246.33 & 20 & & \\
CI & & & & \\
Food & 816.67 & 1 & 76.80 & $<\mathbf{0 . 0 0 0 1}$ \\
Oxygen & 66.67 & 1 & 6.27 & $\mathbf{0 . 0 2 1 1}$ \\
Food $\times$ Oxygen & 54.00 & 1 & 5.08 & $\mathbf{0 . 0 3 5 6}$ \\
Residual & 212.67 & 20 & & \\
Respiration & & & & \\
Food & 8.77 & 1 & 51.75 & $<\mathbf{0 . 0 0 0 1}$ \\
Oxygen & 0.65 & 1 & 3.85 & 0.0852 \\
Food $\times$ Oxygen & 0.47 & 1 & 2.79 & 0.1337 \\
Residual & 1.36 & 8 & & \\
SFG & & & & \\
Food & 29.89 & 1 & 15.86 & $\mathbf{0 . 0 0 4 1}$ \\
Oxygen & 30.91 & 1 & 16.40 & $\mathbf{0 . 0 0 3 7}$ \\
Food $\times$ Oxygen & 32.08 & 1 & 17.02 & $\mathbf{0 . 0 0 3 3}$ \\
Residual & 15.08 & 8 & & \\
\hline & & & & \\
\hline
\end{tabular}

pared between treatments at the termination of the experiment (Day 24) in a 2-way ANOVA, with food (Low and High) and $\mathrm{O}_{2}$ saturation (40 and 100\%) as fixed factors (Table 5). The Medium 100\% treatment was not included in this analysis to maintain a balanced design. Food level was the only factor affecting RNA whereas for CI and SFG food level, $\mathrm{O}_{2}$ saturation and the interaction term were all significant. Respiration rate was significantly affected by food level, with a trend towards an effect of $\mathrm{O}_{2}$ saturation and no significant interaction term (Table 5).

\section{DISCUSSION}

Growth rate is an important component of the overall health status of an individual and changes in individual growth will have cascading effects on population dynamics. The combined effect of food availability and sublethal levels of hypoxia on RNA, CI and SFG in juvenile Paphies australis was tested in 2 laboratory experiments. RNA and CI responded rapidly to increased food availability, but only CI showed a negative influence of hypoxia. Although SFG was affected by both food availability and hypoxia, differences between treatments were not consistent with the other indices. However, respiration rate (a component of the
SFG measurements) showed a pattern similar to the CI. To our knowledge, this is the first study to compare these indices in the same individual bivalves. This combination of physiological measures provides insight into the physiological and behavioural responses that will affect bivalve growth rates and represents information that cannot be deduced using only a single physiological measurement.

\section{RNA and CI respond fast to growth-facilitating factors}

In Expt 2, RNA, CI and respiration rates followed a similar pattern over time, although CI was somewhat more sensitive to hypoxia at maximum food availabilities; this may indicate that hypoxia causes a slowdown in tissue accrual through a decrease in protein synthesis due to lower RNA translational efficiency (Smith et al. 1996, Fraser et al. 2001), although the RNA concentration remains unaffected (Smith et al. 1999). RNA appeared to respond faster to increased food even under hypoxia, as RNA had started to increase in both the High $100 \%$ and High $40 \%$ treatments already after $5 \mathrm{~d}$, while CI had increased only in the High $100 \%$ treatment. Further, the slow decrease in both RNA and CI under both starvation and hypoxia illustrates the slowness of response to negative factors. Thus our results suggest that both RNA and CI respond faster to factors facilitating growth than to factors inhibiting growth, and that especially RNA production is upregulated faster under favourable conditions than it is down-regulated under stressful conditions. This is further supported by observations of significant increases in both RNA and CI in Paphies australis and Austrovenus stutchburyi along gradients of increasing sediment resuspension, i.e. increasing food availability (J. Norkko unpubl. data).

By Day 24, RNA in both the Medium 100\% and High $100 \%$ treatments approached the same level, possibly signifying a size- and species-specific maximum value. The existence of a potential upper and lower limit for RNA in combination with the concept of RNA being upregulated faster than it is down-regulated implies that the response of an individual will depend on its initial condition, with only minor responses expected in bivalves with initial high RNA (e.g. Expt 1). The lower limit for RNA conceivably represents the basal metabolism of the individual, as hypothesised by Houlihan (1991).

The slowly decreasing RNA in Expt 1 could be due to the somewhat higher temperature in February, leading to faster metabolism and higher nutritional demands. As higher temperatures generally decrease organisms' tolerance to hypoxia (Stickle et al. 1989), it is possible that the higher temperature in Expt $1\left(21^{\circ} \mathrm{C}\right)$ con- 
tributed to the mortality, while the metabolism in Expt 2 $\left(17^{\circ} \mathrm{C}\right)$ was slower and the bivalves could survive low $\mathrm{O}_{2}$ saturations for a longer period. However, both temperatures corresponded to temperatures recorded at the collection site. As bivalves were removed from the aquaria during the course of the experiments, the relative food availability increased over time. However, in Expt 1 no effect of increasing food availability was detected after $10 \mathrm{~d}$ and in Expt 2 the main focus was on comparing the 2 low food treatments and the 2 high food treatments, and proportionately these treatments received the same amount of food. Nevertheless, increased food availability could explain the increase in RNA and CI in the Medium 100\% treatment towards the end of Expt 2. Although the results of both Expts 1 and 2 are clear, some uncertainty arises from the use of only 1 aquarium per treatment and the findings may have been further validated by replicating the experiments at the level of the aquaria.

\section{Scope for growth}

The hypoxia in Expt 2 was only moderate, but nevertheless affected feeding rates and thus SFG. Bivalves from the Low $100 \%$ treatment had much higher clearance rates than bivalves from the Low $40 \%$ treatment, even though they had been under fully oxygensaturated conditions for $12 \mathrm{~h}$ prior to the feeding measurements. Similarly, Sobral \& Widdows (1997) reported decreasing clearance rates in Ruditapes decussates under hypoxia and Wang \& Widdows (1993b) found that feeding activity and ingestion rates declined under hypoxia in Mytilus edulis. The high clearance rates in the Low $100 \%$ treatment suggest that bivalves indeed regulate their feeding in relation to physiological needs, with starved individuals filtering more because of a presumed nutritional deficiency. Similarly, the lower clearance rate in the High 100\% treatment on Day 24 may be due to decreasing nutritional demand as the bivalves had been fed well for several weeks. These results are in disagreement with the hypothesis of Jørgensen (1996), who suggests that there is no regulation of bivalve feeding in relation to physiological needs or changes in food regimes. Rather the results support the views of Bayne (1998), who argues that bivalve feeding is a combination of behavioural and physiological characteristics, which respond to changes in food quality and quantity.

SFG measurements have utility both under standardised laboratory conditions, where effects of e.g. pollutants may be separated from effects of e.g. food quality, and under in situ field conditions, where the interaction of environmental factors may be determined. Our SFG measurements exhibited opposite patterns to RNA and CI, with the highest SFG in the Low $100 \%$ treatment. However, as the SFG measurements in this study were obtained under uniform conditions for all treatments, the results do not reflect the bivalves' growth potential in the long term, but rather give an indication of the short-term adaptability of the physiology and feeding behaviour of bivalves that have been subjected to differing food and oxygen regimes prior to the measurements. Therefore both the SFG and its different components need to be considered. As feeding has been positively correlated to respiration rates (e.g. Bayne et al. 1989), the combination of high feeding and low respiration rates in the Low $100 \%$ treatment is not likely to persist. However, over longer time scales SFG and CI are likely to be positively correlated, as reported by Rueda \& Smaal (2004), who found that seasonal changes in SFG were positively correlated with CI in Spisula subtruncata.

\section{Food availability and hypoxia}

Our finding that increased food availability overrides the effect of other factors corresponds well with other studies. Organic enrichment had a significantly larger effect than hypoxia on the growth of the polychaete Nereis diversicolor, the bivalve Abra alba and the brittle star Amphiura filiformis (Hylland et al. 1996). Further, unlike food availability, temperature fluctuations did not affect growth of juvenile scallops Placopecten magellanicus (Pilditch \& Grant 1999). Similarly, a strong positive relationship between nucleic acid ratios (i.e. short-term growth rate) and food availability has been found in bivalves (Wright \& Hetzel 1985, Dahlhoff \& Menge 1996), crustaceans (Wagner et al. 1998, Parslow-Williams et al. 2001) and juvenile and larval fish (Buckley et al. 1999). Yet these studies did not contrast negative and positive effects of stressors like in the present laboratory experiments.

Hypoxia has been recognised as a major problem on a global scale, being increasingly common in coastal areas as a consequence of eutrophication, and it affects marine ecosystems from the sub-cellular to the ecosystem level (Diaz \& Rosenberg 1995). Although hypoxia is known to affect individual growth (Gray et al. 2002, $\mathrm{Wu}$ 2002), relatively few studies have investigated the effect of reduced $\mathrm{O}_{2}$ concentrations on nucleic acid ratios, SFG and CI in bivalves. Sandberg et al. (1996) found no effect on CI in Macoma balthica after $3 \mathrm{wk}$ exposure to hypoxia, whereas Sobral \& Widdows (1997) reported that SFG in Ruditapes decussatus declined after $2 \mathrm{~d}$ exposure to hypoxia. Very small juveniles are likely to be more sensitive. For example, in newly settled oysters Crassostrea virginica shell growth declined in hypoxia and stopped in anoxia $(6 \mathrm{~d}$ 
exposure; Baker \& Mann 1992). In fish, Aday et al. (2000) found significantly lower RNA:DNA ratios in bluegill Lepomis macrochirus caught in hypoxic areas $\left(\mathrm{O}_{2}\right.$ concentration 1 to $\left.3 \mathrm{mg} \mathrm{l}^{-1}\right)$, compared with normoxic habitats. However, they found only nonsignificant trends towards lower RNA:DNA ratios in hypoxia in $7 \mathrm{~d}$ laboratory experiments, whereas food availability had a significant effect. In contrast, Zhou et al. (2001) reported significantly lower RNA:DNA ratios in the common carp Cyprinus carpio after 7 d at $\mathrm{O}_{2}$ concentrations of $1 \mathrm{mg} \mathrm{l}^{-1}$. In crusian carp Carassius carassius hypoxia resulted in lower protein synthesis rates in muscle tissue, due to lower RNA translational efficiency, although the RNA:protein ratio remained high (Smith et al. 1996). In order to maintain vital functions, hypoxia-induced changes in RNA synthesis rates may be tissue-specific (Smith et al. 1999), and may thus not be detected when only muscle tissue is sampled.

\section{Bivalve adaptations}

Some bivalves have efficient strategies for anaerobic energy production (De Zwaan 1977) and may reduce their metabolic rate in response to hypoxia (Storey \& Storey 2004), potentially explaining the slow response in RNA and CI in relation to hypoxia in the present study. Carroll \& Wells (1995) suggested that intertidal species like Paphies australis are well adapted to environmental hypoxia. Similarly, Mayrand et al. (1994) noted that nucleic acid ratios in Mya arenaria did not change until the clams had been emersed for at least $14 \mathrm{~h}$, likely reflecting the adaptation of intertidal animals to regular hypoxia during low tide.

In addition to regulation of metabolic rates, bivalves may mediate their response to changing conditions through regulation of feeding behaviour and absorption efficiency (e.g. Bayne et al. 1987, Hawkins et al. 1996, Iglesias et al. 1996). In the present study the bivalves were fed only high quality food (or no food), with the aim of stimulating or reducing growth. Riisgård et al. (2003) showed that Cardium edule, Mytilus edulis and Mya arenaria reduce their feeding activity in the absence of algal cells, which may represent an adaptation to presumably frequent periods of low algal concentrations in the near-bottom water. This reduces oxygen uptake and consequently metabolism, which could explain the slow rate of decrease in RNA and CI in the Low $100 \%$ and Low $40 \%$ treatments of the present study.

\section{The value of combinations of measures}

A combination of physical and biochemical measures will give a more accurate representation of growth rate, as they reflect processes operating at different time scales (Mathers et al. 1992, Foster et al. 1993). Therefore combinations of measures will be more efficient in the detection of environmental change. For example, Wo et al. (1999) compared RNA:DNA ratios, SFG and shell growth as measures of sublethal effects of cadmium exposure in the gastropod Nassarius festivus; they found that shell growth was the slowest to respond (16 d), and that SFG was somewhat more sensitive than RNA:DNA ratios, but that both responded within $8 \mathrm{~d}$ of exposure and provided similar information. SFG can range from highly positive values under favourable conditions, to negative values when the individual is severely stressed and forced to utilise body reserves for basic metabolism. For example, SFG may be used to monitor environmental contamination over large spatial scales by bringing bivalves from different sites to a single laboratory for physiological measurements under standard, uniform conditions (Widdows et al. 1995). Potentially SFG provides valuable information, as it is an integrated measure of feeding behaviour and metabolic rates, which explains the very short-term (hours) response to changed conditions. However, as feeding behaviour responds rapidly to changed conditions and metabolism responds more slowly, it is necessary to examine these components separately as well as the integrated SFG value and the results need to be interpreted with caution. Respiration rates reflect metabolism over somewhat longer time scales (days) and have been correlated with shell growth, e.g. in Placopecten magellanicus (Pilditch \& Grant 1999). RNA then extends the information on metabolic rates gained from the SFG measurements to providing evidence of the capacity for protein synthesis (days to weeks) and CI reflects changes in body composition and energy reserves, i.e. actual tissue accrual or loss (days to months). Utilising such a suite of measures is thus in accordance with recommendations to use combinations of measures integrating several different levels of ecological organisation for routine environmental impact assessment (GESAMP 1995). It needs to be considered though, that the short-term nature of many individual-level indicators may limit their predictive value as indicators of complex ecological interactions (GESAMP 1995), as relating short-term responses to long-term patterns even at the individual-level is difficult (Giesy \& Graney 1989).

In summary, over the $24 \mathrm{~d}$ covered in this study, hypoxia did not affect RNA and only had a limited effect on $\mathrm{CI}$ and respiration rate. It did however have an influence on SFG, through changes in feeding behaviour. In contrast, food availability had a more direct effect on all measures, with feeding behaviour responding fastest, provided the bivalve had not previ- 
ously been stressed by hypoxia. As RNA in this study was more sensitive to factors facilitating growth than to factors inhibiting growth, it appears that nucleic acid ratios could be good indicators of factors directly related to energy acquisition, while not being as acutely sensitive to stressors. This is particularly important in field applications, where food availability may not be pre-determined or controlled, and could explain why some studies have found only weak responses in nucleic acid ratios in relation to stressors such as hypoxia (Aday et al. 2000), sedimentation (J. Norkko unpubl. data) and pollutants (Foss \& Forbes 1997). As feeding behaviour and depression of metabolic rates likely mediates the bivalve growth response to hypoxia, further investigations on the influence of hypoxia on bivalve growth rates over longer time scales are needed. These experiments illustrate the importance of the combined effects of environmental factors, with differing time scales and magnitudes of effect, which has implications for the design of experiments and surveys, and imply that a combination of measures will give a more accurate representation of growth rate.

Acknowledgements. S. Hatton and C. Lundquist kindly helped with bivalve collection, $\mathrm{S}$. Allen provided the cultured algae, and A. Norkko, J. Hewitt and 3 anonymous reviewers provided valuable comments on the manuscript. M. Thorndyke at Kristineberg Marine Research Station, Sweden, generously provided desk space during manuscript preparation. This research was funded by the New Zealand Foundation for Research, Science and Technology (FRSTCO1X0307), and a National Institute of Water and Atmospheric Research (New Zealand) PhD scholarship and a stipend from Svenska Kulturfonden (Carl Cedercreutz Fund, Finland) to JN.

\section{LITERATURE CITED}

Aday DD, Rutherford DA, Kelso WE (2000) Field and laboratory determinations of hypoxic effects on RNA-DNA ratios of bluegill. Am Midl Nat 143:433-442

Baker SM, Mann R (1992) Effects of hypoxia and anoxia on larval settlement, juvenile growth, and juvenile survival of the oyster Crassostrea virginica. Biol Bull 182:265-269

Bayne BL (1998) The physiology of suspension feeding by bivalve molluscs: an introduction to the Plymouth 'TROPHEE' workshop. J Exp Mar Biol Ecol 219:1-19

Bayne BL, Hawkins AJS, Navarro E (1987) Feeding and digestion by the mussel Mytilus edulis L. (Bivalvia: Mollusca) in mixtures of silt and algal cells at low concentrations. J Exp Mar Biol Ecol 111:1-22

Bayne BL, Hawkins AJS, Navarro E, Iglesias IP (1989) Effects of seston concentration on feeding, digestion and growth in the mussel Mytilus edulis. Mar Ecol Prog Ser 55:47-54

Beukema JJ, Cadée GC (1991) Growth rates of the bivalve Macoma balthica in the Wadden Sea during a period of eutrophication: relationships with concentrations of pelagic diatoms and flagellates. Mar Ecol Prog Ser 68: 249-256
Bricelj VM, Shumway SE (1991) Physiology: energy acquisition and utilization. In: Shumway SE (ed) Scallops: biology, ecology and aquaculture, Vol 21. Elsevier, Amsterdam, p 305-346

Buckley L, Caldarone E, Ong TL (1999) RNA-DNA ratio and other nucleic acid-based indicators for growth and condition of marine fishes. Hydrobiologia 401:265-277

Busing P (1999) Impacts of intertidal macroalgal mats on benthic communities. MSc thesis, University of Waikato, Hamilton

Carroll JL, Wells RMG (1995) Strategies of anaerobiosis in New Zealand infaunal bivalves: adaptations to environmental and functional hypoxia. NZ J Mar Freshw Res 29: $137-146$

Chomczynski P (1993) A reagent for the single-step simultaneous isolation of RNA, DNA and proteins from cell and tissue samples. Biotechniques 15:532-536

Crisp DJ (1971) Energy flow measurements. In: Holme NA, McIntyre AD (eds) Methods for the study of marine benthos. Blackwell Scientific Publications, Oxford, p 197-279

Crosby MP, Gale LD (1990) A review and evaluation of bivalve condition index methodologies with a suggested standard method. J Shellfish Res 9:233-237

Dahlhoff EP (2004) Biochemical indicators of stress and metabolism: applications for marine ecological studies. Annu Rev Physiol 66:183-207

Dahlhoff EP, Menge BA (1996) Influence of phytoplankton concentration and wave exposure on the ecophysiology of Mytilus californianus. Mar Ecol Prog Ser 144:97-107

Dahlhoff EP, Stillman JH, Menge BA (2002) Physiological community ecology: variation in metabolic activity of ecologically important rocky intertidal invertebrates along environmental gradients. Integr Comparative Biol 42:862-871

Dame RF (1993) Bivalve filter feeders and coastal and estuarine ecosystem processes. Springer Verlag, Heidelberg

De Zwaan A (1977) Anaerobic energy metabolism in bivalve molluscs. Oceanogr Mar Biol Annu Rev 15:103-187

Diaz RJ, Rosenberg R (1995) Marine benthic hypoxia: a review of its ecological effects and the behavioural responses of benthic macrofauna. Oceanogr Mar Biol Annu Rev 33:245-303

Ellis J, Cummings V, Hewitt J, Thrush S, Norkko A (2002) Determining effects of suspended sediment on condition of a suspension feeding bivalve (Atrina zelandica): results of a survey, a laboratory experiment and a field transplant experiment. J Exp Mar Biol Ecol 267:147-174

Epifanio CE, Ewart J (1977) Maximum ration of four algal diets for the oyster Crassostrea virginica Gmelin. Aquaculture 11:13-29

Foss HE, Forbes VE (1997) Effects of the polycyclic aromatic hydrocarbon fluoranthene on growth rate and nucleic acid composition of Capitella sp. I. Mar Biol 129:489-497

Foster AR, Houlihan DF, Hall SJ (1993) Effects of nutritional regime on correlates of growth rate in juvenile Atlantic cod (Gadus morhua): comparison of morphological and biochemical measurements. Can J Fish Aquat Sci 50: 502-512

Fraser KPP, Houlihan DF, Lutz PL, Leone-Kabler S, Manuel L, Brechin JG (2001) Complete suppression of protein synthesis during anoxia with no post-anoxia protein synthesis debt in the red-eared slider turtle Trachemys scripta elegans. J Exp Biol 204:4353-4360

GESAMP (Joint Group of Experts on the Scientific Aspects of Marine Environmental Protection) (1995) Biological indicators and their use in the measurement of the condition of the marine environment. Report No. Rep. Stud. GESAMP No. 55, UNEP (United Nations Environment Programme) 
Giesy JP, Graney RL (1989) Recent developments in and intercomparisons of acute and chronic bioassays and bioindicators. Hydrobiologia 188/189:21-60

Gili JM, Coma R (1998) Benthic suspension feeders: their paramount role in littoral marine food webs. Trends Ecol Evol 13:316-321

Gnaiger E (1983) Heat dissipation and energetic efficiency in animal anoxibiosis: economy contra power. J Exp Zool 228:471-490

Goldberg ED, Bowen VT, Farrington JW, Harvey G and 6 others (1978) The mussel watch. Environ Conserv 5:101-125

Gray JS, Wu RSS, Or YY (2002) Effects of hypoxia and organic enrichment on the coastal marine environment. Mar Ecol Prog Ser 238:249-279

Hawkins AJS, Smith RFM, Bayne BL, Héral M (1996) Novel observations underlying the fast growth of suspensionfeeding shellfish in turbid environments: Mytilus edulis. Mar Ecol Prog Ser 131:179-190

Herman PMJ, Middelburg JJ, Koppel Jvd, Heip CHR (1999) Ecology of estuarine macrobenthos. Adv Ecol Res 29: 195-234

Houlihan DF (1991) Protein turnover in ectotherms and its relationships to energetics. In: Gilles $\mathrm{R}$ (ed) Advances in comparative and environmental physiology, Vol 7 . Springer-Verlag, Berlin, p 1-43

Hylland K, Sköld M, Gunnarsson JS, Skei J (1996) Interactions between eutrophication and contaminants. IV. Effects on sediment-dwelling organisms. Mar Pollut Bull 33:90-99

Iglesias JIP, Urrutia MB, Navarro E, Alvarez-Jorna P, Larretxea X, Bougrier S, Heral M (1996) Variability of feeding processes in the cockle Cerastoderma edule (L.) in response to changes in seston concentration and composition. J Exp Mar Biol Ecol 197:121-143

Jørgensen CB (1996) Bivalve filter feeding revisited. Mar Ecol Prog Ser 142:287-302

Lucas A, Beninger PG (1985) The use of physiological condition indices in marine bivalve aquaculture. Aquaculture 44:187-200

MacDonald BA, Bacon GS, Ward JE (1998) Physiological responses of infaunal (Mya arenaria) and epifaunal (Placopecten magellanicus) bivalves to variations in the concentration and quality of suspended particles II. Absorption efficiency and scope for growth. J Exp Mar Biol Ecol 219:127-141

Mathers EM, Houlihan DF, Cunningham MJ (1992) Estimation of saithe Pollachius virens growth rates around the Beryl oil platforms in the North Sea: a comparison of methods. Mar Ecol Prog Ser 86:31-40

Mayrand E, Pellerin-Massicotte J, Vincent B (1994) Small scale variability of biochemical indices of growth in Mya arenaria (L.). J Shellfish Res 13:199-205

Menge BA, Daley BA, Lubchenco J, Sanford E, Dahlhoff E, Halpin PM, Hudson G, Burnaford JL (1999) Top-down and bottom-up regulation of New Zealand rocky intertidal communities. Ecol Monogr 69:297-330

Morton JE, Miller MC (1968) The New Zealand sea shore. Collins, Auckland

Navarro E, Iglesias JIP, Ortega MM (1992) Natural sediment as a food source for the cockle Cerastoderma edule (L.): effect of variable particle concentration on feeding, digestion and the scope for growth. J Exp Mar Biol Ecol 156: 69-87

Newell RIE (2004) Ecosystem influences of natural and cultivated populations of suspension-feeding bivalve molluscs: a review. J Shellfish Res 23:51-61

Norkko A, Hewitt JE, Thrush SF, Funnell GA (2001) Benthic- pelagic coupling and suspension-feeding bivalves: linking site-specific sediment flux and biodeposition to benthic community structure. Limnol Oceanogr 46:2067-2072

Parslow-Williams PJ, Atkinson RJA, Taylor AC (2001) Nucleic acids as indicators of nutritional condition in the Norway lobster Nephrops norvegicus. Mar Ecol Prog Ser 211: 235-243

Pearson TH, Rosenberg R (1987) Feast and famine: structuring factors in marine benthic communities. In: Gee JHR, Giller PS (eds) Organization of communities: past and present. Blackwell Scientific Publications, Oxford, p 373-395

Pilditch CA, Grant J (1999) Effect of temperature fluctuations and food supply on the growth and metabolism of juvenile sea scallops (Placopecten magellanicus). Mar Biol 134: $235-248$

Prins TC, Smaal AC, Dame RF (1998) A review of the feedbacks between bivalve grazing and ecosystem processes. Aquat Ecol 31:349-359

Rheault RB, Rice MA (1996) Food-limited growth and condition index in the easter oyster, Crassostrea virginica (Gmelin 1791), and the bay scallop, Argopecten irradians irradians (Lamarck 1819). J Shellfish Res 15:271-283

Riisgård HU, Kittner C, Seerup DF (2003) Regulation of opening state and filtration rate in filter-feeding bivalves (Cardium edule, Mytilus ediuls, Mya arenaria) in response to low algal concentration. J Exp Mar Biol Ecol 284: 105-127

Rueda JL, Smaal AC (2004) Variation of the physiological energetics of the bivalve Spisula subtruncata (da Costa, 1778) within an annual cycle. J Exp Mar Biol Ecol 301: 141-157

Sandberg E, Tallqvist M, Bonsdorff E (1996) The effects of reduced oxygen content on predation and siphon cropping by the brown shrimp, Crangon crangon. PSZN I: Mar Ecol 17:411-423

Schlenk D (1996) The role of biomarkers in risk assessment. Human Ecol Risk Assess 2:251-256

Schlenk D (1999) Necessity of defining biomarkers for use in ecological risk assessments. Mar Pollut Bull 39:48-53

Shumway SE, Scott TM, Shick JM (1983) The effects of anoxia and hydrogen sulphide on survival, activity and metabolic rate in the coot clam, Mulina lateralis (Say). J Exp Mar Biol Ecol 71:135-146

Smaal AC, Widdows J (1994) The scope for growth of bivalves as an integrated response parameter in biological monitoring. In: Kramer KJM (ed) Biomonitoring of coastal waters and estuaries. CRC Press, Boca Raton, FL, p 247-267

Smith RW, Houlihan DF, Nilsson GE, Brechin JG (1996) Tissue-specific changes in protein synthesis rates in vivo during anoxia in crucian carp. Am J Physiol 217: R897-R904

Smith RW, Houlihan DF, Nilsson GE, Alexandre J (1999) Tissue-specific changes in RNA synthesis in vivo during anoxia in crucian carp. Am J Physiol 277:R690-R697

Sobral P, Widdows J (1997) Influence of hypoxia and anoxia on the physiological responses of the clam Ruditapes decussatus from southern Portugal. Mar Biol 127:455-461

Stickle WB, Kapper MA, Liu LL, Gnaiger E, Wang SY (1989) Metabolic adaptations of several species of crustaceans and molluscs to hypoxia: tolerance and microcalorimetric studies. Biol Bull 177:303-312

Storey KB, Storey JM (2004) Metabolic rate depression in animals: transcriptional and translational controls. Biol Rev 79:207-233

Theede H, Ponat A, Hiroki K, Schliper C (1969) Studies on the resistance of marine bottom invertebrates to oxygendeficiency and hydrogen sulphide. Mar Biol 2:325-337 
Wagner M, Durbin E, Buckley L (1998) RNA:DNA ratios as indicators of nutritional condition in the copepod Calanus finmarchicus. Mar Ecol Prog Ser 162:173-181

Wang WX, Widdows J (1993a) Calorimetric studies on the energy metabolism of an infaunal bivalve, Abra tenuis, under normoxia, hypoxia and anoxia. Mar Biol 116:73-79

Wang WX, Widdows J (1993b) Metabolic responses of the common mussel Mytilus edulis to hypoxia and anoxia. Mar Ecol Prog Ser 95:205-214

Widdows J (1993) Marine and estuarine invertebrate toxicity tests. In: Calow P (ed) Handbook of ecotoxicology, Vol 1. Blackwell Scientific Publications, London, p 145-166

Widdows J, Donkin P, Brinsley MD, Evans SV, Salkeld PN, Franklin A, Law RJ, Waldock MJ (1995) Scope for growth and contaminant levels in North Sea mussels Mytilus

Editorial responsibility: John Gray (Contributing Editor), Oslo, Norway edulis. Mar Ecol Prog Ser 127:131-148

Winberg GG (1960) Rate of metabolism and food requirements of fishes. Fish Res Board Can Transl Ser 194:1-202

Wo KT, Lam PKS, Wu RSS (1999) A comparison of growth biomarkers for assessing sublethal effects of cadmium on a marine gastropod, Nassarius festivus. Mar Pollut Bull 39: 165-173

Wright DA, Hetzel EW (1985) Use of RNA:DNA ratios as an indicator of nutritional stress in the American oyster Crassostrea virginica. Mar Ecol Prog Ser 25:199-206

Wu RSS (2002) Hypoxia: from molecular responses to ecosystem responses. Mar Pollut Bull 45:35-45

Zhou BS, Wu RSS, Randall DJ, Lam PKS (2001) Bioenergetics and RNA/DNA ratios in the common carp (Cyprinus carpio) under hypoxia. J Comparative Physiol B 171:49-57

Submitted: November 5, 2004; Accepted: March 17, 2005 Proofs received from author(s): July 25, 2005 